\title{
Research on Construction of the Network Culture of the Rule of Law
}

\author{
Jiayue Quan ${ }^{1}$ \\ ${ }^{1}$ College of Marxism, Northwestern Polytechnical University, Xi'an, China \\ Correspondence: Jiayue Quan, College of Marxism, Northwestern Polytechnical University, Xi'an, China. Tel: \\ 153-199-38761. E-mail: quanjiayue710062@126.com
}

Received: January 8, 2018 Accepted: February 13, 2018 Online Published: February 22, 2018

doi:10.5539/par.v7n1p1

URL: http://dx.doi.org/10.5539/par.v7n1p1

The research is financed by (Sponsoring information) social science major fund project in 2017 in Shaanxi province (project number: 2017 ZD02); the ministry of education of youth fund project in 2016 (project number: 16 YGC710022); the education science much starker choices-and graver consequences-in planning project In 2016 in Shanxi Province (project number: SGH16H010).

\begin{abstract}
Building the Network Culture of the rule of law is inner pressing for deepening the rule of law practice in China. The basic requirements of the rule of law culture of Network reflected in three dimensions as the value, form and practice, Namely, Citizens of the object, the diversity of culture, and Participate in order. To improve the nature of the citizens of Internet users, to strengthen the rule of law concept education, to construct comprehensive interaction and service network of the rule of law publicity mode, to create the atmosphere of advocating the rule of law, is the route choice of constructing the rule of law culture.
\end{abstract}

\section{Introduction}

The network society is not only an important part of the social reality, but also is an extension of the real society. As the Internet population growing, the Internet has deeply affected every aspect of people's life. The network is a double-edged sword. Network not only brings freedom, democracy, at the same time, but also brought negative energy, such as Internet fraud, Internet rumors and pornography. It leaded to some moral consciousness weakening, moral anomie, and crime, and seriously affected the social harmony. Xi jinping stressed on the second world assembly on the Internet: "cyberspace is not 'the land of extrajudicial'. Cyberspace is a virtual, but the main users of cyberspace is real...To insist on governing according to law network, office network, Internet access, in accordance with the law, in accordance with the law and let the Internet in the health run on the orbit of law." In 19 of the communist party of China, Xi jinping put forward: "we should attaché great importance to the construction of communication and innovation, and improve the news public opinion propagation force, guiding force, influence and credibility. To strengthen the construction of Internet content, the establishment of comprehensive network management system, and build the clear network space." The construction of Network culture of rule of law have to deepen the practice of governing the country according to law as an opportunity, from a high perspective of the construction of political civilization understanding and thinking.

\section{View}

The culture of the rule of law is a kind of political culture of the social universal acceptance and recognition, and is the cornerstone of modern political civilization. The culture of the rule of law is the "soul" of a society of the rule of law, and is the motive force of promoting the rule of law. The rule of law culture, if once formed, will become powerful and lasting power to dominate the whole of society member's behavior.

\subsection{Network Culture Construction of Rule of Law is Inner Pressing Requirements for Deepening the Rule of Law Practice}

The rule of law culture essence, belong to the category of political culture, is the cornerstone of modern political civilization. From the perspective of relationship between democracy and the rule of law, Almond and d, not only emphasized the importance of political culture, "a stable and effective development of democratic government, not only depends on the government and its structure, but also depends on the political culture which is the people to the tendency of the political process ", but also divided the different social political culture 
area into, three types: Regional, obedient, the participated political culture. In their opinion, this kind of social democratic politics that Mainly participated culture, geography and obey social political culture is complementary are easier to stability and development. Huntington thinks which is given priority to the participated political culture is a measure of modern political civilization degree. As the development of network technology and popularization of deep product of network culture, it is cultural form for Internet users to actively participate in as the basic premise. It is characterized a "variable function" such as express desire of citizens, appeal, and behavior of the individual freedom in law field. And it reveals the spirit of modern rule of law culture and value such as freedom, equality, justice, responsibility and orderly participation. Therefore, the rapid rise of the Internet culture is bound to have a significant impact on a country's political culture and democratic rule of law of ecological structure.

As of June 2017, Chinese Internet network information center released by 40 times the China Internet network development state statistic report shows that, the number of Chinese Internet users reached 751 million, Internet penetration rate is $54.3 \%$, and Internet users are 724 million mobile. Network not only becomes the important ways of people to work, study, communication, and entertainment, but also becomes an important platform that the citizens can exercise their right to know, expression, the right of supervision to participate. The development of the network on a country's democratic politics has a deep influence of ecological structure. On the one hand, the network makes the citizen's democratic political consciousness greatly enhanced. On the other hand, the network public opinion reflected the protesters, and it has become to understand public opinion of the government, as the important carrier of community and close ties with the masses. But, in the virtual network, appeared a lot of bad behavior, such as some audio language, "water" in the BBS, false information, network rumors, money laundering, fraud crimes, and "evil do", vulgar cultural phenomenon challenge to ethical and moral bottom line. Especially the network group incidents occurred frequently in recent years, and there are a lot of network chaotic political participation, phenomenon of "media trial". The expression of the irrational, indicates that lack of citizen consciousness of rule of law, also is a kind of network lack of rule of law culture. If there is no fully developed the system of the rule of law culture, the development of socialist political civilization process is hard to avoid setbacks. The benign development of democracy of a country needs synchronous growth of awareness of civil rights and the rule of law. Only right consciousness without the rule of law consciousness, it will only lead to disorderly political participation, lead to disorderly democracy. The rapid growth of democracy in the Network culture will not stop to wait for the consummate laws and regulations.

Therefore, we emphasize with network culture construction of rule of law to regulate network democratic participation, not against network democracy, but are stressed to speed up the urgency and the necessity of network culture construction of rule of law. The urgency and necessity is mainly embodied in three aspects: first, on the strategy of governing the country according to law, it is the urgent needs of the construction to solve the network construction of the rule of law culture research obviously lag behind other aspects of the rule of law culture research; Second, under the strategic concept of cultural confidence and cultural Consciousness, it is the urgent needs for the rule of law culture board to solve the deep contact network. Third, in further advancing the rule of law education system engineering, it is the urgent requirement of rule of law to enhance the rule of law quality of Internet users.

Network virtual community is similar with the realistic community. Not only to promote democracy, it more should emphasize the rule of law order. Democracy is the goal; the rule of law is the guarantee. The rule of law culture of the network emphasizes a kind of rational, social responsibility of public spirit in the virtual space, a kind of equality, open, the rights and obligations of the bidirectional interaction, an independent discipline, democratic participation consciousness and behavior, and is representing the democratic participation spirit and concept of political and cultural forms. Therefore, cultivating network culture plays a very important role in realizing citizen's orderly political participation under the rule of law and promoting the harmonious development of cyberspace,

\subsection{The Basic Requirement of the Rule of Law Culture to Build Contemporary Network}

Network construction of the rule of law culture should not only reflect the generality of rule of law culture, but also reveal the particularity of network culture.

1) The value level: Citizens in Nature of the object

Citizens are the main body of civil society. Civic virtue will directly affect the progress of the society. Internet users are the main part of the network society; the Internet moral quality is directly related to the effectiveness of governance network space. The nature of the citizens emphasized citizen's ability to complete with the authority of the law and obligations. The core of it lies in the identification of the core values of society. Civic virtue is the 
core of the nature of the citizens. Western thinkers that civic virtue summarized into four kinds: general character (courage, discipline, loyalty, etc.), social virtue (independence, open spirit, etc.), economic (work ethic, etc.), the political moral virtue (respect for the rights of others, to engage in public debate will, etc.). The nature of the citizens is corresponds to the rule of law culture, and is ethical value basis to build the rule of law culture. The healthy development of the network virtual society has a certain character of Internet users. The rule of law in the aspect of value, network culture construction lies in the cultivating of citizens in nature.

2) The form level: the diversity of culture

Almond and d think "citizen culture" is a kind of based on communication and belief of multicultural. This cultural diversity is based on communication and persuades, and is consistency and coexistence of cultural diversity. This diversity performance especially in the network culture. Network culture is not only the "equality" culture of information sharing, but also is composed by compatible with diverse culture. In the process of the development of network culture, this diversity makes a citizen's modern ideas such as democracy, freedom and fairness, gradually formed and gradually increases. But pragmatism, utilitarianism, individualism, hedonism, money worship and other values is continuously eroding the thought of the people. It has a serious challenge on the mainstream ideology of a country. In the process of network culture construction under the rule of law, the first thing is to understand and evaluate such forms of diversity culture coexist correctly and objectively. Secondly, We should be rational criticism and draw lessons from foreign culture and consciously resist the influence of bad social network. Thirdly, actively cultivate the Internet users responsibility, equality, and participation, such as public spirit; build in the communication network on the basis of the rule of law culture.

3) The practical level: Participate in the order

Political participation is the so-called "civilians trying to influence government decision-making activities." It can be divided into institutional (legal) and non-institutional political participation (illegal). Orderly political participation is the institutional or legal political participation. Orderly political participation has become the important measure of modern democratic development. Almon said: "if the modern world is undergoing a revolution, we may call this revolution 'participating in revolution." This revolution is the most appropriate used to describe the modern network society. Network culture itself is a kind of culture. Internet users not only tend to input political intention, but also keen to participate in the input process. In the era of network culture, the Internet political participation frequency is higher, and have a sense of responsibility and rational. And this responsibility, recognition, automatic control and other virtue of users are obtained only by participating in and get. Network culture is emphasized in order under the rule of law, namely high rationality on the basis of participation.

\section{Path Selection}

Realistic society needs the system of the rule of law culture, the network as a virtual space more in need of the rule of law culture. Network construction of the rule of law culture is a persistent accumulation process. Strengthening the network moral construction, cultivating citizen of netizens, strengthening the rule of law concept education, building a comprehensive network transmission mode under the rule of law and building the atmosphere of advocating the rule of law, are the inevitable choice of network culture construction of rule of law.

\subsection{To Strengthen the Construction of Network Ethics, Improve the Nature of the Citizens}

Moral cultivation is the core of promoting the Nature of the Citizens in Internet, namely, to continuously strengthen the fairness, the rule of law, good faith and the participation of public spirit, democracy and other ethical morality. The rule of law culture is a natural consistent with ethical culture. Network virtual space management requires not only legal system constraints, more in need of ethical culture internal constraints. Cultivating citizens of Internet users. First of all, we should realize the modernization of the Internet itself, even if it has the power and obligation consciousness of independent personality of citizen. Gradually improve the consciousness of rights and obligations of Internet users in orderly political participation, supervision of the network, network voting. Secondly, Focus on perfecting the relevant laws and regulations on rights and obligations with Internet users, such as "copyright law" to further improve.

\subsection{Concept of Innovating Propaganda Way, Strengthen the Rule of Law Education}

The rule of law concept includes at least the rule of law consciousness and the spirit of rule of law. Network culture construction of rule of law is to make the Internet users forming and promoting the rule of law, practicing law and spreading the basic consciousness of law, forming a human dignity and freedom of spirit, democratic spirit and the basic spirit of the everyone is equal before the law. Network culture construction should highlight the rule of law under the rule of law concept, the rule of law spirit, pay attention to the cultivation of the thinking 
of the rule of law and the rule of law belief, legal knowledge, ideas and thinking through the network training "trinity" of the rule of law culture dissemination, the construction of the system. An effective cultural transmission system should include the subject, object, content, methods and mechanism of organic combination. To build all-round interactive mode, service network of the rule of law propaganda. First of all, it is to perfect the legislation system, further promote scientific legislation, democratic legislation, and pay attention to the timeliness of network laws and regulations, systemic, pertinence and effectiveness. Secondly, it is to improve the internal management of the network, use the integrated of a variety of means such as legal, administrative, ideological and political education innovation management mode, and speed up the formation of management, in accordance with the norms and orderly network management and information dissemination in order. Thirdly, it is to perfect organization, perfect transmission mechanism. We shoud introduce some new carrier, some new forms of the rule of law culture communication, to increase the content of the rule of law culture, so that the network of the rule of law culture is into every person to form the fashion of advocating the rule of law on the network.

\subsection{Enhance the Appeal of the Rule of Law Culture, Build the Clear Network Space}

Only users generate visceral fear of the law, religion, identity, advocating for the rule of law, it is to build the atmosphere of advocating the rule of law on the Internet. This is the highest state of the rule of law culture construction. The characteristics of the culture itself determines the network culture construction should be in the form of more close to the real life with the masses, such as with television, movies, and other rich and colorful cultural activities as the carrier for entertaining, so as to enhance its appeal, influence and penetration.

First, expand the position, and promote the rule of law culture visualization. Currently, the commander of the audience is visual senses ranking "rule" in the network, including sight and sound. This is the rise of Internet culture. In the network society, all kinds of cultural forms, values and social ideological trend is the use of web, We Chat, video and other media, with its outstanding characteristics such as visualization and artistic to attract users and permeate quickly. Therefore, visualization and artistic expression is inevitably choice of culture construction of rule of law on the Internet. Second, we should strengthen the rule of law works of art creation and spread, and promote the rule of law culture to be day-to-day work and life. Through the typical material under the rule of law, case into the film and television, animation creation, further prosperity of rule of law, literature, art, often Publish outstanding works with the artistry of the rule of law and the organic combination. Third, resisting vulgar works, advocate outstanding works with grade, speaking style, responsibility and build the clear network space. At the same time, we should strengthen the mainstream media and government website construction of rule of law, and foster professional network workforce under the rule of law.

\section{References}

CNNIC. (2017). The 40th China Statistical Report on Internet Development. Retrieved from http://www.sohu.com/a/162404995_790657

Gabrielle, A. (1987). Comparative politics, system, process and policy. Shanghai: Shanghai translation publishing house.

Gabrielle, A., \& Sidney, D. (1989). The Civic culture. Hangzhou: Zhejiang people's publishing house.

William, G. (1991). Liberal Purposes: Goods, Virtues, and Diversity in the Liberal State. Cambridge: Cambridge Universes Press.

$\mathrm{Xi}$, J. P. (2015, December 16). Speech at the opening ceremony of the second World Internet Conference. Retrieved from http://news.xinhuanet.com/fortune/2015-12/16/c_1117481089.htm

\section{Copyrights}

Copyright for this article is retained by the author(s), with first publication rights granted to the journal.

This is an open-access article distributed under the terms and conditions of the Creative Commons Attribution license (http://creativecommons.org/licenses/by/4.0/). 